\title{
Diphenylhydantoin and Pulmonary Function
}

\author{
RONALD J.SMITH, GODFREY C. W. MAN, S. F.PAUL MAN, DONALD R. MCLEAN
}

SUMMARY: Thirty-nine epileptic patients underwent pulmonary function testing. Twenty-one of these patients, ranging in age from 16 to 44 years, had taken diphenylhydantoin (DPH) for 2 to 17 years. Eighteen patients, who had taken other anticonvulsants for similar time periods served as controls. Five patients in the DPH group had lung volume abnormalities, four had abnormal airway function, and five had abnormalities of alveolar gas mixing. One patient in the control group had lung volume abnormalities, two had abnormal airway function, and five had abnormalities of alveolar gas mixing. Statistical analysis revealed no significant differences between the groups, or between either group and predicted values.

RÉSUMÉ: Nous avons étudié les fonctions pulmonaires chez 39 patients épileptiques. 21 de ces patients, de 16 à 44 ans, avaient pris du diphenylhydantoin (DPH) pour des périodes de 2 à 17 ans. 18 patients ayant reçu d'autres anticonvulsivants pendant des périodes de temps équivalentes ont servi de témoins. Du groupe DPH, cinq patients présentaient des anomalies du volume pulmonaire, quatre avaient des fonctions aériennes anormales et cinq des anomalies de mélange des gaz alvéolaires. Dans le groupe contrôle, un patient avait des anomalies du volume pulmonaire, deux des fonctions aériennes anormales et cinq des anomalies de mélange des gaz alvéolaires. Ces résultats ne s'avèrent pas être significativement différents entre les deux groupes ou en fonction des valeurs prédites.

From the Department of Medicine, Divisions of Neurology and Pulmonary Medicine, University of Alberta, Edmonton.

Presented in part at the Thirteenth Annual Meeting of the Canadian Congress of Neurological Sciences, Vancouver, June, 1978.

Supported by the University of Alberta Hospital Special Services and Research Committee.

Reprint Requests to: Dr. D. R. McLean, Division of Neurology, 9-101 Clinical Sciences, University of Alberta, Edmonton, Alberta, T6G 2G3, Canada.

\section{INTRODUCTION}

Diphenylhydantoin (DPH) has been in common use as an anticonvulsant since 1938 (Merrit and Putnam, 1938). Its side effects are protean (Sparberg, 1963). Controversy exists regarding the effects of DPH on the pulmonary system (Moore, 1959; Low and Yahr, 1960; Livingston, 1961; Hazlett et. al., 1974; Bayer et. al., 1976).

This study was designed to investigate the effects of long term DPH therapy on pulmonary function and if possible, to elucidate the mode of action of any effect produced.

\section{MATERIALS AND METHODS}

Thirty-nine epileptic patients were selected for the study, all of whom gave no history of cigarette smoking, occupational exposure to factors likely to cause pulmonary dysfunction or overt cardio-pulmonary disease. The patients were divided into two groups on the basis of medication history.

One group, ten females and eleven males (age range 16-44 years, mean 29 years) had been on DPH alone for more than two years (range 2-17 years, mean 7 years). The other group, eleven females and seven males (age range 14-44 years, mean 23 years) had been on other anticonvulsants for similar time periods, and served as controls.

All participants answered a standardized questionnaire on respiratory symptoms (MRC Committee on Chronic Bronchitis, 1966). In addition, physical examination, chest $\mathrm{x}$ ray, electrocardiogram, full blood profile, serum $B_{12}$ and folate levels, $\alpha_{1}-$ antitrypsin, anti-DNA antibodies and $\mathrm{C}_{3}$ and $\mathrm{C}_{4}$ levels were performed.

All patients underwent extensive pulmonary function testing. This included lung volume by spirometry and functional residual capacity by a helium dilution method. Results obtained were compared with predicted values (Boren et. al., 1966). Forced expiratory volumes and forced expiratory vital capacities were obtained by spirometry. Airway resistance was measured by body plethysmography (Dubois et. al., 1956), and values obtained were compared with normal data from our own laboratory. Flow volume loops were obtained on all patients (Black and Hyatt, 1974). Closing volumes and phase III slope were measured using a modified single breath nitrogen technique, and values obtained were compared with the data of Buist (1973). Diffusion capacity was measured at rest, by single breath (Bates et. al., 1955), and steady state techniques (MacNamera et. al., 1959) results being compared with normal data (Bates et. al., 1962). Alveolararterial oxygen differences were performed before and after exercise on all patients. Oxygen tension was considered correct within $\pm 2 \mathrm{mmHg}$.

\section{RESULTS;}

None of the patients showed any abnormalities of the respiratory or cardiovascular systems on physical examination. Chest $\mathrm{x}$-rays were interpreted by a radiologist with no knowledge of the study. All were reported as normal. All patients had normal electrocardiograms. There were no abnormalities of serum $B_{12}$ levels, $\alpha_{1}$-antitrypsin, anti-DNA antibodies, or $\mathrm{C}_{3}$ and $\mathrm{C}_{4}$ levels.

One patient in the DPH group had a hemoglobin of $10.5 \mathrm{G} / \mathrm{dl}$. This was not associated with macrocytosis, and the folate level was normal. Three other patients in the DPH group had low serum folate levels without macrocytosis or anemia. In the control 
TABLE 1

Lung Volumes

\begin{tabular}{lcccc}
\hline & TLC (\% Pred) & VC (\% Pred) & FRC (\% Pred) & RV/TLC (\%) \\
\hline $\begin{array}{l}\text { Dilantin } \\
\text { Group }\end{array}$ & $113.95 \pm 14.06$ & $104.80 \pm 14.68$ & $123.05 \pm 27.88$ & $29.39 \pm 7.92$ \\
$\begin{array}{l}\text { Control } \\
\text { Group }\end{array}$ & $110.22 \pm 10.20$ & $98.39 \pm 10.89$ & $130.67 \pm 18.77$ & $30.67 \pm 7.10$ \\
p Value & N.S. & N.S. & N.S. & N.S. \\
\hline
\end{tabular}

Table 1-Lung volumes for DPH group and control group. Figures are mean \pm I S.D.

(TLC - total lung capacity; VC - vital capacity; FRC - functional residual capacity; $\mathrm{RV}$ - residual volume).
Mean closing volume for the DPH group is slightly higher than that of the control group, but of doubtful significance, with $\mathrm{p}<0.05$, but $>0.02$. Values for both groups are well within predicted normal values (Buist, 1973). Mean values for phase III slope are within normal limits for both groups.

Results of gas exchange studies are given in Table 4. There is no statistical difference between the groups, or from predicted values.

Table 5 shows the number of individual abnormalities of pulmon-

TABLE 2

Airway Function

\begin{tabular}{|c|c|c|c|c|c|}
\hline & $\mathrm{FEV}_{1} / \mathrm{VC}(\%)$ & v̇50 (\% Pred) & نे75 (\% Pred) & Raw $\mathrm{CmH}_{2} 0 / \mathrm{L} / \mathrm{sec}$ & SGaw $\left(\mathrm{cmH}_{2} \mathbf{0} \cdot \sec ^{-i}\right)$ \\
\hline $\begin{array}{l}\text { Dilantin } \\
\text { Group }\end{array}$ & $85.95 \pm 6.71$ & $95.58 \pm 21.58$ & $81.86 \pm 23.81$ & $1.41 \pm 0.54$ & $0.260 \pm 0.071$ \\
\hline $\begin{array}{l}\text { Control } \\
\text { Group }\end{array}$ & $84.67 \pm 6.78$ & $91.83 \pm 26.97$ & $87.67 \pm 25.52$ & $1.55 \pm 0.34$ & $0.219 \pm 0.056$ \\
\hline p Value & N.S. & N.S. & N.S. & N.S. & N.S. \\
\hline
\end{tabular}

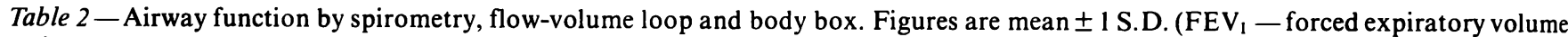
in 1 second; Raw - airway resistance; SGaw - specific airway conductance).

TABLE 3

Closing Volume

\begin{tabular}{lcc}
\hline & CV/VC (\%) & $\begin{array}{c}\text { Slope of Phase III } \\
\left(\% \mathrm{~N}_{2} / \mathrm{L}\right)\end{array}$ \\
\hline $\begin{array}{l}\text { Dilantin } \\
\text { Group } \\
\text { Control }\end{array}$ & $12.54 \pm 8.18$ & $1.76 \pm 1.02$ \\
$\begin{array}{l}\text { Group } \\
\text { p Value }\end{array}$ & $7.56 \pm 6.85$ & $1.85 \pm 0.71$ \\
\hline
\end{tabular}

Table 3-Closing volumes (CV) and phase III slopes obtained from closing volume curves by single breath nitrogen technique. Mean \pm 1 S.D.

group five patients had low folate levels, one of which was associated with a slight macrocytosis, but none were anemic.

The results of pulmonary function testing are considered under four subdivisions; lung volume, airway function, closing volume and gas exchange.

Table I shows the results for each group with respect to lung volume. Statistical analysis reveals no significant difference between the groups, or between either group and predicted values (Boren et. al., 1966).

The results of airway function testing are shown in Table 2. The $\dot{V} 50$ and $\dot{V} 75$ are the expiratory flow rates at $50 \%$ and $75 \%$ of vital capacity, respectively, as calculated from the flow volume loop. There is no significant differences between the groups, or from predicted values (Dubois et. al., 1956; Black and Hyatt, 1974).

Table 3 shows mean values for closing volumes, and the slopes of phase III of the closing volume curves. ary function encountered in the DPH group. Of note is the fact that with the exception of patient \#19, who was the oldest patient in the study, and whose results indicated mild airways obstruction, the abnormalities were scattered, and followed no pattern. Also of note was the absence of any significant abnormality of gas exchange. Abnormalities of the control group are shown in Table 6 . Once again the abnormalities followed no pattern, and there is no abnormality of gas exchange. If we compared the number of abnormalities in each group, by test of proportion (Table 7) they were of no statistical significance. For technical reasons, three of the DPH group did not have closing volume measurements.

\section{DISCUSSION}

Since the introduction of DPH (Merrit and Putnam, 1938), a wide variety of undesirable side effects have been reported, affecting almost every body system. Controversy exists in the literature regarding the effects of the drug on the pulmonary system. 
TABLE 4

Gax Exchange

\begin{tabular}{|c|c|c|c|c|c|c|}
\hline & $\begin{array}{c}\text { DCO } \\
\text { (\% Pred) }\end{array}$ & $\begin{array}{c}\text { DCO }_{b b} \\
\text { (\% Pred) }\end{array}$ & $\begin{array}{l}\mathrm{pO}_{2} \text { Rest } \\
(\mathrm{mm} \mathbf{H g})\end{array}$ & $\begin{array}{c}\mathrm{pO}_{2} \text { Exercise } \\
(\mathrm{mm} \mathrm{Hg})\end{array}$ & $\begin{array}{c}\text { A-a } \mathrm{DO}_{2} \text { Rest } \\
(\mathrm{mm} \mathrm{Hg})\end{array}$ & $\begin{array}{c}\mathrm{A}-\mathrm{a} \\
(\mathrm{mm} \mathrm{Hg})\end{array}$ \\
\hline $\begin{array}{l}\text { Dilantin } \\
\text { Group }\end{array}$ & $116.05 \pm 27.42$ & $96.0 \pm 11.34$ & $89.95 \pm 9.55$ & $89.05 \pm 8.08$ & $12.77 \pm 5.49$ & $15.43 \pm 5.17$ \\
\hline $\begin{array}{l}\text { Control } \\
\text { Group }\end{array}$ & $108.46 \pm 34.71$ & $101.5 \pm 27.72$ & $88.94 \pm 8.04$ & $90.0 \pm 7.44$ & $14.36 \pm 7.88$ & $12.92 \pm 5.24$ \\
\hline p Value & N.S. & N.S. & N.S. & N.S. & N.S. & N.S. \\
\hline
\end{tabular}

Table 4-Carbon monoxide diffusion by steady state $\left(\mathrm{DCO}_{\mathrm{as}}\right)$ and single breath $\left(\mathrm{DCO}_{\mathrm{sb}}\right)$ methods. Alveolar-arterial oxygen differences $\left(\mathrm{A}-\mathrm{aDO}_{2}\right)$ at rest and after exercise. Figures are mean \pm 1 S.D.

TABLE 5

Pulmonary Function Tests - Dilantin Group

\begin{tabular}{l|l|l|l|l||l|l|l|l||l|l||l|l|l|l|l|l} 
Dilantin \\
Group
\end{tabular}

Table 5-Number of abnormalities in the DPH group on pulmonary function testing. 
TABLE 6

Pulmonary Function Tests - Control Group

\begin{tabular}{l|l|l|l|l||l|l|l|l||l|l||l|l|l|l|l|l} 
Control \\
Group
\end{tabular}

Table 6-Number of abnormalities in the control group on pulmonary function testing.

TABLE 7

Dilantin vs Control

\begin{tabular}{lcccccc}
\hline & FRC & RV/TLC & FEV $_{1} /$ VC & Vं75 & CV & $\begin{array}{c}\text { Slope of } \\
\text { Phase III }\end{array}$ \\
\hline Dilantin & $3(21)$ & $3(21)$ & $0(21)$ & $4(21)$ & $1(18)$ & $4(18)$ \\
Control & $1(18)$ & $1(18)$ & $2(18)$ & $1(18)$ & $0(18)$ & $5(18)$ \\
p Value & N.S. & N.S. & N.S. & N.S. & N.S. & N.S. \\
\hline
\end{tabular}

Table 7-Comparison of numbers of abnormalities in each group by test of proportion.

In 1959, Moore reported the development of plain radiographic changes characteristic of diffuse pulmonary fibrosis in $87 \%$ of 31 patients who had taken DPH for two or more years. This claim was quickly refuted by Low and Yahr (1960), who studied 113 unselected patients who had been taking DPH for 2 to 22 years. None of the patients showed any radiographic evidence of diffuse pulmonary fibrosis or significantly accentuated bronchovascular markings. In 41 of these patients, chest $\mathrm{x}$ rays taken at the time of starting DPH, were available for comparison.

In 1961 Livingston studied 43 patients who had been on DPH for 2 to 12 years, and could find no significant chest $x$-ray changes, or abnormalities of vital capacity. Hazlett and Ward (1974) reported significant pulmonary function changes in a group of otherwise normal patients, aged 11 to 56 years, who took DPH alone or in combination with other anticonvulsants for two or more years. Forty-five percent of their patients had a reduced diffusion capacity, and $50 \%$ had a widened alveolar-arterial oxygen difference after exercise. The abnormalities were equally distributed between those patients who took DPH alone, or in combination with other anticonvulsants. There were no abnormalities of gas exchange in our patients.

Although our population is not entirely comparable with the Denver population of Hazlett and Ward (Denver altitude $5,280 \mathrm{ft}$. Edmonton 2,280 ft.), their predicted values for $D_{\text {co }}$ seem high, particularly in younger patients, where the majority of the reported abnormalities occurred. Using the predicted values of MacNamera et. al. (1969) the majority of these patients would fall 
within the normal range with respect to diffusion capacity.

The total number of abnormal results, when our patients are considered as a group, appears higher than expected, especially in the highly sensitive pulmonary function tests (five out of thirty-nine in $\dot{V} 75$ and nine out of thirty-six in slope of phase III). Since an abnormal $\dot{V} 75$ has been suggested to be an indication of early airflow obstruction, and an abnormal slope of phase III uneven alveolar gas mixing, it is possible that these epileptic patients have developed subtle pulmonary changes. However, the exact interpretations of these tests are not uniformly accepted, and indeed may not be indicative of definite pulmonary disorder. Moreover, as previously mentioned, since the abnormalities are not preferentially distributed in one group, it is unlikely that dilantin is completely responsible for disturbance in lung function.

We are unable to support the findings of Moore, or those of Hazlett and Ward. Our results clearly show that therapeutic doses of DPH for periods ranging from 2 to 17 years do not produce any changes in plain chest $\mathrm{x}$-ray and have no significant effect on pulmonary function. It is suggested that final resolution of the matter will require long term control prospective studies.

\section{REFERENCES}

BATES, D. V., BONCOT, H.G., DORMER, A. E. (1955). The pulmonary diffusing capacity in normal subjects. J. Physiol. (Lond.) 129: 237.

BATES, D. V., WOOLF, C. R., PAUL, G. I. (1962). A report on the first two stages of the coordinated study of the chronic bronchitis in the Department of Veterans Affairs, Canada, Can. Med. Serv. 18: 211-303.

BAYER, A. S., TORGAN, S. R., PITCHMAN, S. E., GUZE, L. B. (1976). Dilantin toxicity: Miliary pulmonary infiltrates and hypoxemia. Ann. Intern. Med. 85: 475-476.

BLACK, L. F., OFFORD, K., HYATT R. E. (1974). Variability in the maximal expiratory flow volume curve in asymptomatic smokers and in non-smokers. Am. Rev. Respir. Dis. 110: 282-292.

BOREN, H. G., KORY, R. C., SNYER, J. C. (1966). The Veterans Administration-Army cooperative study of pulmonary function. Am. J. Med. 41: 96-114.

BUIST, A. S., ROSS, B. B. (1973). Predicted values for closing volumes using a modified single breath nitrogen test. Am. Rev. Respir. Dis. 107: 744-752.
DUBOIS, A.B., BOTELHO, S.Y., COMROE, J. H. (1956). A new method for measuring airway resistance in man using a body plethysmograph; values in normal subjects and in patients with respiratory disease. $\mathrm{J}$. Clin. Invest. 35: 327-335.

HAZLETT, D. R., WARD, G. W., MADISON, D. S. (1974). Pulmonary function loss in diphenylhydantoin therapy. Chest 66: 660664.

LIVINGSTON, S., WHITEHOUSE, D., PAULI, L. L. (1961). Study of the effects of diphenylhydantoin sodium on the lungs. $\mathrm{N}$. Engl. J. Med., 264: 648-651.

LOW, N. L., YAHR, M. D. (1960). The lack of pulmonary fibrosis in patients receiving diphenylhydantoin. JAMA 174: 1201-1202.

MacNAMERA, J., PRIME, F. J., SINCLAIR, J. D. (1959). An assessment of the steady state carbon monoxide method of estimating pulmonary diffusion capacity. Thorax 14: 166.

MERRIT, H. H., PUTNAM, T. J. (1938). Sodium diphenylhydantoinate in the treatment of convulsive disorders. JAMA 111: 1068-1133.

MOORE, M. T. (1959). Pulmonary changes in hydantoin therapy. JAMA 171: 1328-1333.

SPARBERG, M. (1963). Diagnostically confusing complications of Diphenylhydantoin therapy. Ann. Intern. Med. 59: 914-930. 